\title{
Actinomycosis mimicking sinonasal malignant disease
}

\author{
Alberto Maria Saibene, Daniele Di Pasquale, Carlotta Pipolo, Giovanni Felisati
}

Otolaryngology Department, San Paolo Hospital, University of Milan, Milan, Italy

\section{Correspondence to} Professor Giovanni Felisati, giovanni.felisati@gmail.com
To cite: Saibene AM, Di Pasquale D, Pipolo C, et al. BMJ Case Rep Published online: [please include Day Month Year] doi:10.1136/ bcr-2013-200300

\section{DESCRIPTION}

A 46-year-old man was referred to our ear nose throat clinic for the right nasal obstruction, purulent nasal discharge, mid-facial swelling and upper right gingival retraction since 6 months. He had previously received antibiotic therapy with temporary relief. Nasal endoscopy showed medialisation of the right uncinate process, while the oral examination revealed a swelling of the upper right alveolar arch. The head CT (figure 1) showed an expansive mass occupying the right maxillary sinus. The suspicion of neoplastic disease led to perform an MRI with contrast medium (figure 2). Despite the high suspicion of fungal disease after MRI, which showed a fungal-like central signal void, the patient underwent an explorative endoscopic procedure to rule out a neoplastic condition.

The intraoperative examination excluded malignancies and the procedure was completed with a wide middle antrostomy that allowed toileting the mixed necrotic and fungal-like material occupying the sinus. The known odontogenic cyst-the likely odontogenic focus-was also removed endoscopically. The histopathological examination resulted in actinomycosis and the patient recovered after long-term antibiotic therapy (intravenous ceftriaxone $2 \mathrm{~g}$ four times a day for 1 month, followed by oral amoxicillin clavulanate $1 \mathrm{~g}$ three times a day for 3 months). There was no relapse during the 1-year follow-up.

Actinomycosis is a rare condition with frequent cervicofacial involvement caused by Actinomyces spp. ${ }^{1}$ In case of sinonasal involvement, the unresponsiveness to antibiotic therapy alone requires thorough surgical debridement. ${ }^{2}$ As for all

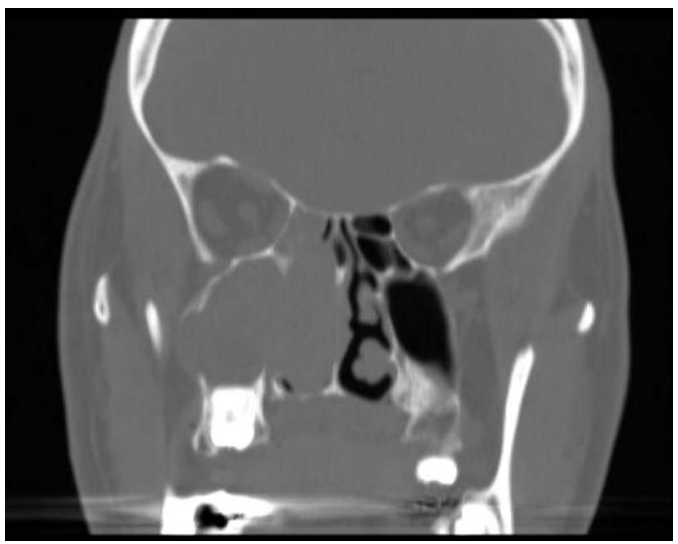

Figure 1 Coronal CT scan of the paranasal sinuses showing an expansive mass of the right maxillary sinus. The mass erodes the inferior, medial and lateral walls of the sinus and an ethmoidal involvement was observed.

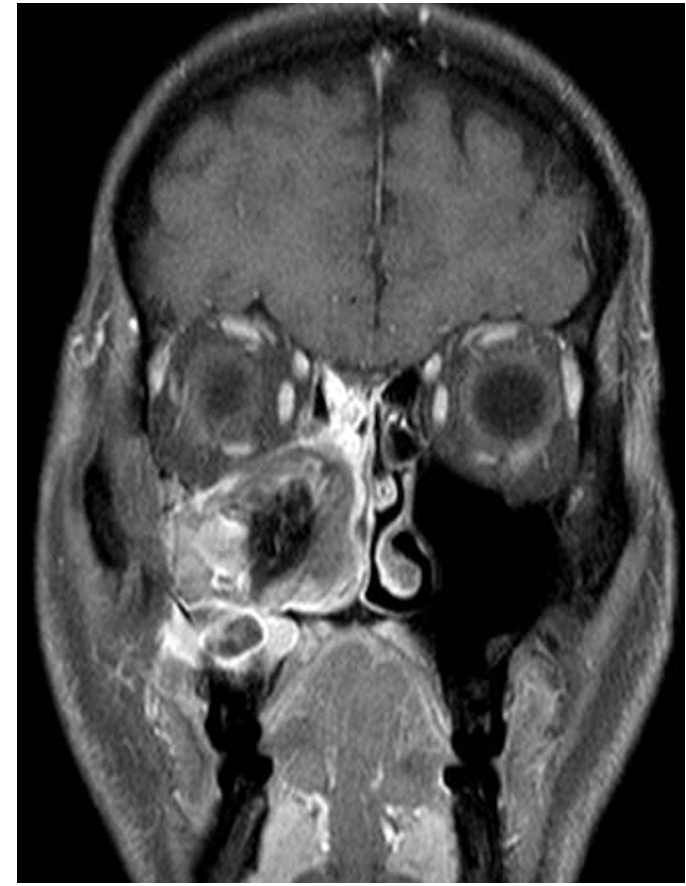

Figure 2 Coronal T1-weighted MRI of the paranasal sinuses showing an expansive mass of the right maxillary sinus characterised by the lack of tissue infiltration and contrast enhancement with a markedly dishomogenous signal. MRI identified three components of the mass, a mucosal thickening of the right maxillary and ethmoidal sinuses (suggesting an inflammatory reaction), a maxillary signal void (suggesting a fungal disease), and a maxillary odontogenic cyst, which was already known to the patient.

odontogenic sinonasal conditions presenting no signs of oroantral fistulae, this case was treated according to the literature with nasal endoscopy and long-term antibiotics. ${ }^{3}$

\section{Learning points}

- Despite its rarity, actinomycosis should be taken into differential diagnosis when imaging studies show an expansive mass with significant bony erosion.

- Always examine patients' dental history when addressing sinonasal conditions, no matter how unrelated to dental treatments may they appear.

- While the surgical treatment of actinomycosis is similar to the other odontogenic sinonasal diseases, long-term antibiotic treatment is required to achieve complete recovery. 
Contributors CP and GF performed the surgical procedure. AMS and DDP retrieved data and images and wrote the article.

Competing interests None.

Patient consent Obtained.

Provenance and peer review Not commissioned; externally peer reviewed.

\section{REFERENCES}

1 Vorasubin N, Wu AW, Day C, et al. Invasive sinonasal actinomycosis: case report and literature review. Laryngoscope 2013;123:334-8.

2 Woo HJ, Bae CH, Song SY, et al. Actinomycosis of the paranasal sinus. Otolaryngol Head Neck Surg 2008;139:460-2.

3 Felisati G, Chiapasco M, Lozza P, et al. Sinonasal complications resulting from dental treatment: outcome-oriented proposal of classification and surgical protocol. Am J Rhinol Allergy 2013;27:101-6.

Copyright 2013 BMJ Publishing Group. All rights reserved. For permission to reuse any of this content visit http://group.bmj.com/group/rights-licensing/permissions.

BMJ Case Report Fellows may re-use this article for personal use and teaching without any further permission.

Become a Fellow of BMJ Case Reports today and you can:

- Submit as many cases as you like

- Enjoy fast sympathetic peer review and rapid publication of accepted articles

- Access all the published articles

- Re-use any of the published material for personal use and teaching without further permission

For information on Institutional Fellowships contact consortiasales@bmjgroup.com

Visit casereports.bmj.com for more articles like this and to become a Fellow 